\title{
Inservice Training Programme Preference of Teachers in the Multidisciplinary Approach of Implementing Environmental Education
}

\author{
Omoogun, Ajayi C. \& Omoogun, Remi Modupe \\ Faculty of Education, University of Calabar, Nigeria \\ E-mail: Omoogun.ajayi@yahoo.com
}

Received: April 3, 2013

Accepted: May 1, 2013 Published: May 1, 2013

doi:10.5296/jse.v3i2.3469

URL: http://dx.doi.org/10.5296/jse.v3i2.3469

\begin{abstract}
The study was undertaken to determine the inservice preference of teachers in the multidisciplinary approach to implementation of environmental education curriculum in Cross River State, Nigeria. The study adopted the descriptive survey design. The sample consisted of 737 teachers proportionally sampled from 67 public secondary schools in the three education zones of Cross River State. The result revealed that teachers' prefer workshop as a mode of professional development to enable them implement EE curriculum. Their subject area also have significant influence on their inservice training preference in the implementation of environmental education curriculum. Based on the findings, it was recommended among others that in the adoption of the multidisciplinary approach in the implementation of EE curriculum In-service training programmes with emphasis on workshop should be organized very often and on the basis of teachers' competency needs and subject area.
\end{abstract}

Keywords: Inservice, Multidisciplinary, Implementation, Environmental Education 


\section{Introduction}

It is common knowledge that schools are the custodians of society's culture, and they perform a variety of functions in a given society. Johnson, Dupuis, Musial and Hall (1994:17) have enumerated these school functions as follows:

i. Reproduction: Schools act to preserve tradition and heritage, and they carry out decisions about what to teach based on the customs and traditions of the past.

ii Readjustment: Schools alter programmes in response to social change.

iii. Reconstruction: Schools are agents of change in the society.

Citing the colonial reliance on education to transform the natives, Emeh (2002) affirmed that the educational system and its institutions have always functioned as revolutionary, reformationary, and conservationary. This perhaps informed the world wide conviction that environmental education is vital for achieving success in the domain of environmental conservation and sustainability(Michaelis,1980;Duguet,1992; Emeh,2002;UNESCO,2003)

The International Conference on Environmental Education (1977) in Belgrade and the

Intergovernmental Environmental EducationConference (1977) in Tbilisi recommended that environmental education is to be taught using the multidisciplinary approach. It is argued by many researchers that separate subject approach is not suitable for teaching $\mathrm{EE}$ at the secondary school level, because the time table at this level is already crowded (Noibi, 1990; Yisa, 1990); that many teachers have not been trained for the implementation of EE (Eguabor, 1999; Emeh, 2006); and that since environmental matters cut across boundaries of regular knowledge classification it gives validity to the multidisciplinary approach chosen by the National Council on Education (Abdullahi, Ango and Olarinoye, 2000). Under the multidisciplinary approach, topics in Environmental Education are plugged at appropriate points in the existing subjects which serve as the carriers of Environmental Education messages and concepts. By this approach, the environmental education curricular would be implemented through all the traditional school subjects taught in the schools. UNESCO-UNEP (1997) indicated that the choiceof a particular approach in curriculum development involves a consideration of the following aspects; ease of implementation, teacher competencies and training demand or curriculum load, ease of curriculum development and evaluation.

At the center of all these is the teacher who ultimately is the implementer of the curriculum. On a general note, the disposition of teachers is very essential in the implementation of any curriculum. Onwuka (1996:211) commented on the importance of teachers noting the need to involve the teacher in all phases of curriculum planning can hardly be over emphasized. To begin with, that a curriculum has been designed to feature appropriate educational experiences is no guarantee that corresponding appropriate educational experiences will result. Much of the educational experience which may result in the end will depend on teachers. It is on the efforts of teachers that a curriculum which has been designed by planners in a society depends, to a large extent, for its success in terms of leading 
toappropriate ends of education in the society. Teachers are a key factor in the operation and for the success of curriculum; they are indispensable in the educative process.

Behind every successful implementation of curriculum project or policy are highly trained, motivated and efficient classroom teachers (Usman and Agwagah, 2001). The National Policy on Education (Federal Republic of Nigeria, 2004:39) observed that 'no educational system or policy can Rise above the quality of its teachers'. The role of teachers in achieving a sustainable environment via the implementation of Environmental Education is a very cardinal one. Mgbodile (2003) had noted that the importance of the teacher in determining the tempo of curricular and methodology cannot be underestimated. He noted that plans and policies can be well laid on paper, the implementation strategies well outlined, and the organizational structure well set but it is the teacher factor that stands as the deciding factor in terms of whether or not the desired goals and objectives which had informed all the efforts can be achieved. Many researchers have reiterated the fact that teacher disposition and characteristics which includes -what teachers think, believe and do, their experience, qualification, sex and location of teaching ultimately determine their level of performance and the quality of education (Ogah, 2004; Odetoyinbo, 2004; Domike, 2002; Onwuka, 1996).

Kosemani and Kpolovie (2003) revealed that teachers tend to perceive distinct needs according to their personal factors such as qualification, teaching experience, and knowledge of subject matter, gender, school location and their area of specialization. The successful implementation of any curriculum requires the availability of trained and experience teachers.

\section{Statement Of Problem}

The educational system has understandably been looked upon as the viable means for influencing the behavior of man and future generations. The focal point or core area of any form of education is the curriculum. It is on the curriculum that we build the expectations for students, the materials to be used in the teaching and learning process and the training for teachers. Environmental education curricula have been developed in 1998 in Nigeria by the Nigerian Educational Research and Development Council for the secondary schools level.

The most important element in the implementation of the Environmental Education curricula is the teachers. Given the multidisciplinary approach, all the teachers are involved in the implementation of the goals and objectives of the environmental education curriculum through the subject they teach; and given the fact that teachers received no formal training in $\mathrm{EE}$, what basic knowledge do they require to teach EE? What type of inservice training would they prefer in this direction?

\section{Literature}

Teaching is a challenging profession especially in these changing times and to meet the demand of a changed and still changing society, there is driven need for the development of well-qualified individuals who posses the requisite knowledge and skills (Aina, 1990). Perhaps, this is why the Tbilisi conference deplored the inadequate environmental education background of professional groups which has led to their inability to perceive the multifaceted character of environmental problems. Training personnel especially teachers 
came out in a survey (UNESCO/ENVED 6, 1977) as the greatest need of environmental education on a world-wide scale. Teachers in formal education need training in environmental education to familiarize them with the subject matter and the educational and methodological guidelines in environmental education. In-service environmental training is therefore recommended for all teachers, of any field of specialization, who have not had any formal training in the field before (UNESCO-UNEP, 1990). The benefits derived from in-service training of teachers do not end at the teacher level but filter all the way to the students.

In-service education is defined as the application of appropriate means to promote the professional growth and development of workers while on the job. It includes planned and organized efforts to improve the knowledge, skills and attitudes of instructional staff to make them more effective on the job (Good, 1973). It has also been defined as all planned professional activities designed to improve the technical and pedagogical competencies of teachers. The National Policy on Education (2004) noted that teacher education will continue to take cognizance of changes in methodology and curriculum and as a result teachers will be regularly exposed to new innovations. The policy stated that in-service training will be developed as an integral part of continuing teacher education.

The dynamic nature of knowledge and by extension teaching and learning makes it necessary for teachers to be learners all the times. For instance, Okebukola (1999) has noted that with the information technology pervading all human affairs in the $21^{\text {st }}$ century including education, an effective teacher must be current, knowledgeable about new development and trends.

Adeboyeje (2000) argued that refresher courses for teachers no doubt develop in each teacher his general education and personal culture, his ability to teach and educate others and awareness of principles which underlie good human relations. Rao and Rao (1997) state that training and retraining programme for employees improves changes, mould the employee's knowledge, skills, behavior, aptitude and attitude towards the requirement of the job. While Ojedele (2000) argues that refresher courses for workers enable them to acquire the necessary skills to do what they have been performing better than they have been doing before. Edem (1982) and Obi (2000) in their various studies found that retraining programme for teachers improved them both academically and professionally and apart from helping teachers to update their knowledge, it serves as a motivating factor for teacher's efficiency. They further maintain that retraining programme can take the form of shot courses, seminars, workshops and conferences, weekend courses, vacation courses and ad hoc courses. Asuquo (2000) observed that our educational system is witnessing a continuous growth, thus making the need for teacher training and retraining very crucial and necessary. He argues that teaching requires professional training to give the individual enough skills in the art of impacting knowledge to the learner. Accordingly, retraining programme for serving teachers is aimed at changing human character, perception, attitude and adding new knowledge and experience to the participants. Akpabio (2000), Kida (2000) and Isyaku (1991) all agreed that, there is need to retrain new and inexperienced teachers as well as those who have been in service for years as this would help them to learn new teaching techniques, change their perception and attitude towards the teaching profession. 
Agwubike (1986) opined that since teaching in Nigeria is not strictly professional and most teachers enter into the teaching profession with an increasing varied background of academic, professional and occupational experiences, there is need for a reliable in-service education programme if such teachers must assume responsibility for training students. According to Shulman (1992), teachers need to master two types of knowledge - content knowledge and knowledge of the curricular development. Content knowledge encompasses what Bruner (as cited in Shulman, 1992) called the 'structure of knowledge'- theories, principles and concepts - of a particular discipline. They also need to know about curriculum resources and technologies and how to structure instruction so that learning can occur. According to Ball and Cohen (1996), acquiring this sophisticated knowledge and developing a practice that is different from what teachers themselves experience during training requires additional learning opportunities.

Okon and Sule (2005) have recommended in-service and refresher courses and various professional development programmes as the panacea for the eradication of the seemingly psychological brutalization and entrenched professional incapacitation of teachers: the key challenges facing curriculum implementation. Mwanoruo (1998) suggested that in-service training programmes should offer a variety of opportunities for teachers. He suggested that while effectiveness in teaching should be stressed for teachers who have little experience in teaching, in-service should be made available on a regular basis so that all practicing teachers can periodically sharpen their occupational skills and knowledge. Omoogun (2001) insisted that if we must be participants in the $21^{\text {st }}$ century developmental thrust, the production of teachers must be done within the demand of contemporary society. This according to him can be done by providing regular in-service to teachers to update their knowledge not only in their teaching subjects but in general knowledge about contemporary issues.

According to Esu (2005), the attainment of a functional and qualitative education will be a mirage without adequate and well trained and qualified teachers to meet the challenges of the school system vis-à-vis the myriad changes which have been brought into our society in general and the school system in particular. Esu (2005) further called for a deliberate policy and substantial investment in training and re-training of teachers.

Teachers are indispensable partners in the successful implementation of environmental education and their empowerment in the knowledge, skills, values and methodology of environmental education is bound to have multiplier effect on learners. Noibi (1990) noted that, inadequate curriculum content of environmental education is not only the challenge facing environmental educationbut inadequate teacher preparation. He found out that less than $25 \%$ of secondary school teachers of the 300 sample for study used the physical environment to teach or make analogy with it. All these imply that most teachers are handicapped in effective teaching which involves the physical environment. Refresher courses would develop in each teacher ability to teach and educate others (Adeboyeje, 2000), improves changes and moulds teachers knowledge, skills, behavior, attitude (Rao and Rao, 1997) acquire necessary skills to do what they have not been to do before and perform better in what they have been doing (Akpan and Ntukidem, 2005). Akpabio (2000) and Kida (2000) all agreed that there is need to retrain teachers both experienced and inexperienced ones so 


\section{Macrothink}

that they can learn new teaching techniques and new content areas which are changing from time to time.

According to the National Commission for Colleges of Education (1990), in addition to the required qualifications, teachers are expected to be updating their knowledge through various staff development programmes such as workshops, seminars, conferences and refresher courses. Ojo (1999) noted that participation in in-service programmes stimulates and enhances professional growth, updating and upgrading of knowledge and skills as well as facilitating access to professional journals and experts. Accordingly, Carew (1991) opined that the extent to which opportunities are utilized to promote the dissemination of environmental education depends on the environmental preparedness of teachers. The current crops of teachers are not prepared to teach EE so what type of inservice training do they need to implement environmental education?

\section{Research Question}

The basic question this research sort to answer is: what type of in-service training will the teachers prefer to enable them implement EE?

\section{Methodology}

The research design adopted for this study was the descriptive survey. This study was conducted in Cross River State (CRS). The state consists of eighteen (18) local government areas. The state is made up of 3 educational zones with 228 post primary institutions consisted of 3352 teachers.

\section{Sample and Sampling Technique}

The sample for the study included 737 teachers selected from 67 public secondary schools in CrossRiverState using a multi-stage proportionate sampling technique. First, the schools in the state were stratified along three educational zones. Calabar zone has 72 public secondary schools, Ikom has 86 and Ogoja has 70 public secondary schools giving a total of 228 public secondary schools across the three zones.

To ensure a representative sample from the population, the proportionate sampling technique was adopted. For each zone, $30 \%$ of the schools were randomly selected for the study. This gave 21, 25 and 21 schools from Calabar, Ikom and Ogoja zones respectively making a total of 67 schools.

\section{Results}

The null hypothesis states that there is no significant difference in the mean rating of teachers of various subjects in their in-service preference

To test the hypothesis, Contingency $\mathrm{X}^{2}$ chi-square analysis was applied to the data.

The result is presented on table 1. 


\section{Ml Macrothink}

Journal of Studies in Education

ISSN 2162-6952

2013, Vol. 3, No. 2

Table 1. Summary of chi-square analysis of the relationship between teacher's subject area and in-service performance

\begin{tabular}{|l|l|l|l|l|l|}
\hline \multirow{2}{*}{ SN } & \multirow{2}{*}{ Teaching Subject } & \multicolumn{2}{l|}{ INSERVICE TRAINING PREFERENCE } & \multirow{2}{*}{ Total } \\
\cline { 3 - 5 } & & Workshop & Higher Degree & Certificate/Diploma & \\
\hline 1 & English Language & $48(55.8)$ & $22(25.5)$ & $16(18.6)$ & $86(100)$ \\
\hline 2 & Mathematics & $68(72.3)$ & $16(17.0)$ & $10(10.6)$ & $94(100)$ \\
\hline 3 & Integrated Science & $55(64.0)$ & $14(16.3)$ & $17(19.8)$ & $86(100)$ \\
\hline 4 & Social Studies & $93(48.9)$ & $84(44.2)$ & $13(6.8)$ & $190(100)$ \\
\hline 5 & Introductory Technology & $39(62.9)$ & $10(16.1)$ & $13(21.0)$ & $62(100)$ \\
\hline 6 & Religious knowledge & $20(71.4)$ & $6(21.4)$ & $2(7.1)$ & $28(100)$ \\
\hline 7 & Agricultural Science & $58(72.5)$ & $10(12.5)$ & $12(15.0)$ & $80(100)$ \\
\hline 8 & Business studies & $42(65.6)$ & $6(9.4)$ & $16(25.0)$ & $64(100)$ \\
\hline 9 & Music & $03(75.0)$ & $1(25.0)$ & $-(0)$ & $4(100)$ \\
\hline 10 & Physical \& Health Edu & $22(75.9)$ & $7(24.1)$ & $-(0)$ & $29(100)$ \\
\hline 11 & French & $4(50.0)$ & $1(12.5)$ & $3(37.5)$ & $8(100)$ \\
\hline 12 & Home Economics & $4(66.7)$ & $-(0)$ & $2(33.3)$ & $6(100)$ \\
\hline & Total & $456(61.9)$ & $177(24.0)$ & $104(14.1)$ & $737(100)$ \\
\hline
\end{tabular}

Table 1 shows that the chi-square analysis produced an observed $x^{2}$ of 45.38 , which was statistically significant at 0.05 probability level. This result implies that null hypothesis is rejected suggesting that there is a significant relationship between teacher's subject area and their in-service preference.

The table further reveals that a greater proportion of subjects in all subject areas $(52 \%$ and above) tend to prefer seminar/workshop to other forms of inservice training (higher degree \& certificate courses) with relatively small proportion of responses.

\section{Discussion and Recommendations}

The result revealed that teachers preferred workshops as means of improving their competence needs for effective implementation of the EE curriculum. This result is in consonance with Sowande (2002) who found that majority of teachers preferred that their in-service programme for the improvement of their competence be conducted through workshops. Akpan and Ntukidem (2005), Akpabio (2000) and Kida (2000) all agreed that there is need to retain teachers both experienced and in-experienced ones so that they can learn new teaching techniques and new content areas which are changing from time to time. The dynamics nature of knowledge and the need to disseminate them on time makes workshop most preferred by teachers because of the short-nature of workshop than the post-graduate programmes. Teachers may also have opted for workshop over seminars because of the skills, knowledge and interaction they will be exposed to within a short period of time. As Richard and Killen (1996) pointed out, in-service training is designed to improve professional competences of servicing teachers after their initial training. Through this, according to Sistrunk (1986), the teachers renew their competences in teaching. 
Teachers preference for workshops as a means of retaining programme requires government and all stakeholders in EE to sponsor and organize workshops on very regular basis to keep the teachers abreast with new concepts, knowledge and pedagogy of EE and about the environment and to disseminate same in the classroom.

\section{References}

Adeboyeje, R. A. (2000). Teacher training and utilization for quality education in Nigeria. In J. O. Fadipe and D. K. Ojedele (eds). Management of Nigeria Education: Personnel Administration and Quality in Education. NEPA, Ibadan: Daily Graphics. 89-91.

Aina, F. O. A. (1990). Strategies for effective teaching of environmental education in schools. Environmental Education workshop and seminar proceedings, 1, 107-114.

Akpabio, J. E. (2000). Training and retraining of teachers for the Universal Basic Education International. Journal of Basic and Life Long Education, $1(1$ \& 2). 357-358.

Akpan, C. P., \& Ntukidem, P. J. (2005). Teachers perception of training and retraining programme and their attitude toward work in public secondary schools in Cross River State. Journal of World Council for Curriculum Instruction: Nigeria Chapter Forum, 5(2), 78-84.

Asuquo, E. E. (2000). The Universal Basic Education: implication for teachers training and retraining. International Journal of Basic and Life Long Education, 1 (1\&2), 337.

Carew, B. A. R. (1991). A key note address at the workshop on Environmental Education for secondary school teachers. Environmental Education. A workshop and seminar proceedings, $1,97-100$.

Esu, A. E. O. (2005). Capacity building curriculum: A necessity for sustainable development. Journal of World Council for Curriculum Instruction: Nigeria Chapter Forum, 5(2) 1-13.

Good, C. V. (1973). Dictionary of Education. Third Edition. New York: McGraw Hill Book Company.

Kida, M. A. (2000). The Community educaton in action. Lagos: El Demak.

Lierhamier, A. D. (1996). Programme development for inservice teacher education in the New York State Education department. Abstract of a report prepared by Basic System Inc. for the division of Teacher Education and Certification. New York: Education Department. August 17.

Noibi, A. S. (1990). Challenges of environmental education in Nigeria Schools. Environmental Education. Workshop and Seminar Proceedings, 1, 80-91.

Obi, F. B. (2000). Recruitment, training and retention of teachers as basic tools to success of Universal Basic Education. International Journal of Basic and Long Life Education, 1(1\&2), 270-273.

Ojedele, P. K. (2000). Enhancing educational productivity through effective staff personnel administration in Nigerian schools. In E. O. Fagbamiye \& D. O. Durosaro (eds). Educational 
and Productivity in Nigeria. NEASP, Illorin: Haytee Press.

Ojo, A. A. (1999). A study of professional growth of teachers in selected technical colleges in Niger State. In G. D. Momoh (ed). Issues in Curriculum Development and Innovation for Sustainable Technology Education in Nigeria. Lagos: Nigerian Association of Teachers of Technology.

Okebukola, P. A. O. (1999). Empowerment through education for scientific and technological development: challenges for $21^{\text {st }}$ century. Keynote address presented at the $3^{\text {rd }}$ Annual Conference of STAN (Lagos State branch). $28^{\text {th }}-30^{\text {th }}$ June.

Okon, J. E. \& Sule, M. A. (2005). The challenge of teacher professionalism and curriculum implementation: polemics and praxis. Nigerian Journal of Curriculum Studies, 12(2), 44-48.

Omoogun, A. C. (2001). Teachers views on the standard of education and their image in the $21^{\text {st }}$ century. West African Journal of Educational Research, 4(2), 74-80.

Rao, P. S. \& Rao, V. S. P. (1997). Personnel/human resource management: Text, cases and games. Delhi: Konark publishers.

Shulman, L. (1992). Ways of seeing, ways of knowing, ways of teaching, ways of learning about teaching. Journal of Curriculum studies, 28, 393-396.

UNESCO-UNEP International Environmental Education Programme. (1990). Strategies for the implementation of the environmental dimension of secondary school science. Environmental Education Module for Inservice training of Science teachers and supervisors for secondary schools series, 8, 165-176. 